\title{
Knowledge Generation, Dissemination and Adoption in an Agro-industry: The Role of an Institutional Network
}

\author{
Anuar Md Nor*, Rosmimah Mohd Roslin \\ Universiti Teknologi MARA, Malaysia
}

Copyright (C) 2015 by authors, all rights reserved. Authors agree that this article remains permanently open access under the terms of the Creative Commons Attribution License 4.0 International License

\begin{abstract}
The Malaysian palm oil industry has become a major and diversified industrial sector over a period of forty years. Several palm oil firms have expanded internationally by establishing oil palm plantations in other developing countries, as well as by acquiring firms in developed countries. In addition, the Malaysian palm oil industry had managed to develop new technologies to improve production yields and create new products for consumers. Our study aims to analyze the role of an institutional network in the palm oil industry in the generation and sharing of new knowledge. It is suggested that this institutional network creates industry competitive advantages through the development and application of industry best-practices. A qualitative approach was used to have an in-depth understanding of the institutions involved in the institutional network and the types of interactions that take place among the key institutions for knowledge generation and sharing. The study involved gathering of primary data through in-depth interviews of key managers of palm oil palms, representatives of industry associations, government officials and senior staff in an industry-funded R\&D institute. The main result of our findings shows that new knowledge is generated by on-going research activities of an industry R\&D institute, which is managed as a government entity. The $R \& D$ institute is required to share the new knowledge with firms in the palm oil industry. It is found that the R\&D institute tapped the knowledge of a global network of experts to search for new information and technology directions, which we call expert informational network (EIN). The institutional network is further reinforced by informal linkages among institutions and executives in the Malaysian palm oil industry. These relationships have been propagated by several generations of industry executives, industry leaders and heads of governmental units.
\end{abstract}

Keywords Agro-industry, Inter-organizational Relationships, Knowledge Sharing

\section{Introduction}

As compared to manufacturing firms from developing countries, agro-industrial firms are rarely studied. UNCTAD [1] notes that agro-industrial firms are becoming significant contributors to international trade. Despite this, very few studies have been undertaken, with the exception of Rama [2], to understand these agro-industrial firms in international business, and their competitive advantages.

Agro-industrial firms are distinguished from manufacturing firms by the agricultural origins of most of their material inputs, which are perishable in nature. The planning of production and transformation processes and achieving of economies of scale can be fraught with difficulties, especially when there are specific quality parameters. Thus, there is an incentive for agro-industrial firms to engage in primary production themselves or to develop long-term supply relations with agro-producers.

A large agro-industry requires complex coordination among many parties and the establishment of processing and export facilities, requiring significant investments. Agro-industrial firms must also develop close relationships with other institutions, such as government research institutes, universities, and agricultural governmental bodies, to avoid calamities, such as diseases, which can destroy an entire agro-industry with substantial economic consequences. Research activities are also important to improve plant or crop productivities and develop disease-resistant varieties. The cost of research on these activities is enormous due to its long-term nature, and there is a need to pool the financial and technical resources of many parties to conduct research for mutual benefits. The success of the research efforts can be shared among the agro-industrial firms in addressing common industry problems.

\section{Institutional Network Ties in the Malaysian Palm Oil Industry}

The Malaysian palm oil has been recognized as a successful agro-industry and contributes to substantial earnings of exports of processed products. The palm oil 
industry is controlled by domestic palm oil firms, and they are involved from the production of palm oil to the marketing of palm oil products. The palm oil industry has managed to develop diverse palm oil products, which are used in foods and industrial applications. The generation of new knowledge and the commercialization of new products are achieved due to the presence of a strong institutional network.

This paper discusses a research that we have undertaken to study the characteristics and contents of the institutional network. The study also aims to identify focal institutions that drive the enduring relationships in the palm oil industry.

\section{Context of the Study}

The Malaysian palm oil industry is an ideal case study for research on knowledge generation, dissemination, and absorption in an agro-industry in a developing country.

First, the Malaysian palm oil industry is the engine for product development in the industry. Although originated from Africa, the Malaysian palm oil industry has successfully developed the oil palm as a plantation crop for export. The Malaysian palm oil industry has evolved from just planting oil palms. Over a period of forty years, the Malaysian palm oil industry became a major producer of high-valued products for industrial applications. These technological developments were achieved through consistent technology accumulation process based mainly on local technology capacity.

Second, there is direct government involvement in the palm oil industry, from the licensing of business activities to that of ownerships of palm oil firms. This has allowed the government to monitor and develop the palm oil industry through the ownership of palm oil firms to build the industry infrastructure, such as logistics and foreign direct investments.

Third, Malaysian palm oil firms have been active in internationalization process since the 1990s by undertaking foreign direct investments both in the plantation sector and the processing sector [3]. Several Malaysian palm oil firms own large plantations in Indonesia, Papua New Guinea and Liberia. The internationalization process is supported by management expertise and industry best-practices, which had been developed in the Malaysian operations. Six Malaysian palm oil firms were in the list of top twenty five transnational corporations in agribusiness industries ranked by foreign assets in 2007 [1].

Fourth, there are concerted efforts between palm oil firms and governmental institutions in the generation of new knowledge and absorption of this new knowledge in the palm oil industry. Specialized R\&D institutions developed know-how in products and technologies to support product promotions in new markets. An efficient palm oil cluster had been established, which creates an embedded business network that links governmental units, palm oil firms, industry associations, industry experts and research institutions.

\section{Research Objectives}

The research objectives of the study are as follows:

1. To examine the role of networks of institutions, research institutes, industry associations and agro-industrial firms in generating and sharing of new knowledge to create industry competiveness.

2. To examine the role of an industry-funded research institute in the identification, discovery and adoption of new knowledge in an agro-industry.

3. To examine the environmental factors that impact on the formation of networks in the creation of new knowledge in an agro-industry.

In line with the research objectives, our guiding questions are:

1. What are the key institutions and how do the interactions take place among them?

2. How do these interactions generate industry advantages?

3. What are the features that characterize the interactions among the institutions within the palm oil industry?

In order to understand the issues related to the research questions, a thorough review of the literature on inter-organizational relationships and knowledge sharing was conducted. This study follows Eisenhardt's [4] suggestion of building a theory with predetermined propositions, as these may bias and limit the findings. Nevertheless, it is acknowledged, even by Eisenhardt, that it is impossible to approach any research with no theory under consideration at all. Therefore, in line with Eisenhardt, the review of related existing literature provides a useful theoretical framework in which to operate.

\section{Theories on Inter-organizational Relationship and Knowledge Sharing}

Researchers have emphasized the importance of relationship assets or social capital [5,6,7]. This line of research emphasizes assets, resources and advantages based on a firm's network of relationships with other organizations, including other firms and governmental units. Social capital theory maintains that competitive advantages can be derived not only from firm-level resources but also from difficult-to-imitate capabilities embedded in network relationships [6]. The networks of strong personal relationships, which had developed over time, provide the basis for trust, cooperation, and collective actions in communities [8]. Researchers have found that social capital encourages cooperative behavior, thereby facilitating the establishment of relational associations and organizations [9].

Other scholars have suggested that institutional network ties provide critical advantages for firms in developing countries [10]. Institutional network ties refer to linkages 
with various domestic institutions such as government officials, banks, universities and trade associations. Krackhardt [11] shows that when ties are strong, partners are more willing to exchange information and cooperate for mutual benefits.

The network concept describes the structures of relationship formed by connected and interacting actors. Firms not only operate in business networks, but interact also with economic and social organizations, and institutions [12]. Networks constitute forms of voluntary cooperation that involve information sharing, mutual learning and exchange between their members as well as social control. Firms and organizations obtain relevant information by means of their involvement in different networks [13]. In a network, resources as well as learning experiences become shared, making a complex system that is difficult to imitate, and, therefore, creates industry competitiveness [14].

Business networks are viewed as structures of inter-firm relationships and evolve through continuous interactive process, which is called embeddedness by Granovetter [15]. He introduces the concept of embeddedness as firms' relation with, and dependence on various types of networks. These social relationships form on-going structures which have their own histories. The network model presented by Hakansson and Johanson [16] suggests that a network comprises three substantive dimensions, namely actors, activities and resources. They relate to one another and form the general structure of a business network.

Dyer and Nobeoka [17] explain that sharing between companies and organizations in a network faces several potential problems. Sharing knowledge is often not in the interest of a company, which creates a potential motivation problem. Free-riding is another threat to knowledge sharing in inter-organizational networks. A network partner may be inclined to reap the benefits from acquiring knowledge without intending to contribute to others.

Trust and commitment, thus, must exist to facilitate knowledge sharing in a network. This is because trust results in stability of relationships and confidence in the interaction of network partners. In addition, confidence and stability are important conditions for ongoing interactions and deep exchanges [18]. In a situation with sufficient trust, partners are not afraid of knowledge spillovers, and the firm's decision-makers and employees are less likely to protect themselves against opportunistic behavior by their partners [19].

Kogut [20] suggests that having a shared identity means that individuals share a sense of purpose and belonging with other members of a collective. Such a network identity can also develop with a network of organizations. Knowledge is most effectively shared by individuals who identify with a larger collective and consider other network members to be "one of us". They become motivated to contribute to that collective and to share even tacit or core knowledge [17,20]. Furthermore, Dyer and Nobeoka [17] argue that a shared identity establishes explicit and tacit rules of coordination. Individuals sharing a network identity know what to expect from each other.

According to resource dependent theory [21], organizations participate in inter-organizational relations to acquire resources they need in order to survive and to manage their dependency on the environment. Two forces drive the formation of inter-organizational relations, namely competition and cooperation. The forces of competition and cooperation lead to the formation of two distinctive types of organizational relations. The first is based on resource exchange, and the second is based on the interpretation of organizational boundaries [22]. Resource-based links allow the transfer of specific resources such as funds, personnel and technology, as well as more general resources such as power and influence. However, beyond the goal of resource transfer, organizations build ties with each other when in transactional relations [23]. This leads to the formation of inter-organizational ties based on the interpretation of organizational boundaries [22]. In building such ties, organization give up certain level of autonomy in exchange for reduced uncertainty and the achievement of collective goals.

Tang [24] suggests that there are two different types of inter-organizational knowledge networks, namely transactional knowledge network and interactive knowledge network. The transactional knowledge network involves a one-way transfer of knowledge from one organization to another through formal, contractual channels. Knowledge sharing in the transactional knowledge network is mainly based on short-term exchange-based transaction. The interactive knowledge network, on the other hand, allows for two-way sharing of knowledge through informal, long-term interactions and communications. These modes of knowledge sharing complement each other [25]. The knowledge sharing processes in these two knowledge networks differ in term of the nature of knowledge shared, the nature of ties, and the outcome of knowledge sharing, as shown in Table 1.

Table 1. Characteristics Of Knolwdge Sharing Networks

\begin{tabular}{|c|l|l|}
\hline & \multicolumn{1}{|c|}{ Transactional knowledge networks } & \multicolumn{1}{c|}{ Interactive knowledge networks } \\
\hline Nature of knowledge shared & $\begin{array}{l}\text { Codified, migratory knowledge, high market } \\
\text { readiness, low stickiness }\end{array}$ & $\begin{array}{l}\text { Tacit and codified, embedded knowledge, low } \\
\text { market readiness, high stickiness }\end{array}$ \\
\hline $\begin{array}{c}\text { Characteristics of the knowledge } \\
\text { sharing process }\end{array}$ & $\begin{array}{l}\text { Short-term, formal, contractual, resource exchange, } \\
\text { arm's length, exploitative }\end{array}$ & $\begin{array}{l}\text { Long-term, informal, knowledge spillover, } \\
\text { embedded, exploratory }\end{array}$ \\
\hline Outcome of knowledge sharing & Knowledge shared & Knowledge shared and created \\
\hline
\end{tabular}

Source: Tang [24] 
While resource exchange in the transactional knowledge network is based on the assumption of self-interest, the interactive knowledge network is characterized by collaborative ties based on the premise of mutual interests [26].This type of network has a more or less cohesive goal, and organizations in such a community often are likely to engage in long-term collaborations with each other rather than short-term transactions. Such a community-based network often has a centralized structure, which facilitates the realization of collective goals and the diffusion of knowledge [27].

Thus, organizations participate in the interactive and transactional knowledge networks out of different motivations. Organizations establish short-term transactional ties to acquire resources they need, including knowledge, data material and capital. They also enter interactive ties such as R\&D collaborations or interlocking directorate to access knowledge and to take advantage of the social capital of their partners. The structures of the transactional knowledge networks and interactive knowledge networks are shaped by the various institutional and contextual factors of that country.

Based on the review of the literature, we have identified a number of gaps in the existing literature. First, firms from smaller Asian economies such as Thailand and Malaysia dominate certain agro-industry sectors and have used their domestic advantages to expand internationally. Second, the success of these countries' agro-industrial firms is dependent on formal inter-organizational relationships among local institutions, which are orchestrated by their governments. However, the impacts of these inter-organizational relationships on knowledge generation and knowledge sharing have not been studied systematically. Furthermore, the number of theoretical and empirical studies using the institutional perspective in developing countries is limited, even though some theorists have argued that this institutional perspective is the most applicable paradigm for explaining firms' behaviour in developing countries [28].

\section{Methodology}

The study adopts a qualitative approach, as the main objective of the study is to have an in-depth understanding of interactions among key institutions in the palm oil industry. The main methodology used to collect primary data was in-depth interviewing of informants from these institutions. The interviews were made in the offices of the informants and were audio-taped for transcription. A substantial amount of data of annual reports of institutions, conference papers, workshops and proceeding was also collected. The researcher also attended several seminars, conferences and presentations to observe interactions in the palm oil industry.

The theoretical perspective of the study has been guided by symbolic interaction perspective $[29,30]$. The symbolic interaction perspective places primary importance on the social meaning individuals attach to the world around them.
The period of the study was twenty months, commencing from October 2011 until May 2013. During this period, 18 informants were interviewed, and six conferences/seminars were attended. A semi-structured interview guide was used so as to allow the researcher to develop themes and to refine the results of the findings. The informants interviewed comprised a diverse number of individuals, which we have identified from their institutions that form the palm oil institutional network. The informants included:

i. R\&D staff of major palm oil firms;

ii. General managers of industry associations;

iii. Government officials in charge of the palm oil industry; and

\section{iv. Industry experts}

These informants were selected based on their knowledge of the palm industry and the involvement of their institutions in the formal network of the palm oil industry. Their institutions were considered important organizations as they are often quoted in government documents. As the researcher had a reputable corporate background, the informants were generally very approachable and were generous in sharing their experiences in knowledge generation and knowledge sharing in the palm oil industry. They were aware of the purpose of the research and were proud of the achievements of the palm oil industry. The interviews were transcribed verbatim and generated more than 200 pages of document. The primary and secondary data was analyzed using the usual techniques of qualitative approach.

\section{Discussions of Results}

The study had identified a close network that facilitate knowledge generation, knowledge sharing and knowledge absorption in the Malaysian palm industry. The close network was formed as a result of historical contexts and on-going interactions promoted by focal institutions with responsibilities to develop the palm oil industry. This close network, which we term the palm oil institutional network, links an industry-funded R\&D institute with palm oil firms, governmental institutions, industry associations and groups of technical and scientific experts. The inputs from on-going and close interactions are utilized by the industry-funded $R \& D$ institute to develop its $R \& D$ programs, especially medium- and long-term $\mathrm{R} \& \mathrm{D}$ efforts, which are avoided by commercial interests of palm oil firms.

An informant described the palm oil industry network as follows:

We start with the ministry. Then we have the Malaysian Palm Oil Board (MPOB), the research side, doing research on the up-stream, mid-stream and down-stream and as a regulator. They also give advice to the planters or the smallholders. Then, we go down to the palm oil council, who will do marketing for our products. Next, we have the 
associations, the Malaysian Palm Oil Association (MPOA), Palm Oil Refinery Association of Malaysia (PORAM), all those guys.

Further up, we have the minister. Whatever decisions to be made, we pass it to the minister and will be taken up to the cabinet level. We have all ears to the industry. We have a lot of dialogues (with the industry). We have also other consultations. We have all the ears to the industry because the industry contributes so much to the country, so that they can do their business well to bring back the money to the country.

Five types of network, which collectively create the palm oil institutional network, have been identified. These networks are; (1) government-mandated technological networks, (2) industry associational network, (3) institutional policy network, (4) government-linked corporate networks, and (5) expert informational networks.

The government-mandated technological networks (GTN) were formed by government legislations to formulate and undertake $\mathrm{R} \& \mathrm{D}$ activities for the palm oil industry. The main components of the GTN are a government R\&D institute for palm oil industry, important industry associations, major palm oil firms, and technical expert communities. The government $R \& D$ institute (MPOB) is funded through a collection of levies paid by palm oil firms. The government R\&D institute formulates its research activities through inputs by industry associations, technical expert communities and members of industry associations on the board of the government R\&D institute. A senior manager of the MPOB describes the interactions:

Several mechanisms...the first one is the board of directors (of MPOB). The board comprises member representations from the industry. A lot, sixteen representatives, all included...the ministry, industry associations, FELDA ${ }^{1}$...FELDA is a special case. The board members are to cover the needs of the industry.

The government $R \& D$ institute actively shares its $R \& D$ findings with palm oil firms through technology bulletins, conferences, workshops and technology licensing. It is the main generator of new knowledge for the palm oil industry over the last thirty years. This new knowledge is widely discussed among palm oil firms. As example was that the discovery of an African weevil for the pollination of oil palm by a private palm oil was quickly adopted by other palm oil firms, thereby increasing the overall productivity of the palm oil industry.

The government R\&D institute has helped to create a formal network for knowledge sharing in the palm oil industry. A founding former senior manager of the government $R \& D$ institute noted:

1 FELDA means Federal Land Development Authority, the largest government-owned palm oil company in Malaysia.
I said to my researchers whatever we find we must tell the industry, but we have to do it in the efficient way. We don't want to spend our time travelling all over Malaysia. We attend seminars and conferences. Every two years, I hold international conferences. And after that, we have seminars between conferences...that is technology sharing. If you want to know you come and pay but at that time we only charge to cover costs. Our intention was not to make money...our intention was to give information at the most efficient way so that people come and listen.

The industry associational networks are the earliest business networks in the palm oil industry. Initially these industry associations acted as social organizations for members and planters. As the palm oil industry expanded, these associations were invited by the government to be involved in policy-making committees. These industry associations are a key component in the dissemination of information among its members. An important industry association is the Incorporated Society of Planters, whose members are managers of the plantation industry, and helps, formally and informally, in sharing of industry best-practices.

The industry associations help to create institutional routines, which are represented by regular interactions among various institutions. Firms in the palm oil industry are involved in guiding the direction of the palm oil industry through industry associations. An informant from an industry association notes:

Everything our members need to know or something, our members get. Any form of information we will send to our members. We get all the information from our interactions with different associations. We have many regular interactions to make ourselves relevant.

Institutional policy networks are linkages used by governmental units to develop policies affecting the palm oil industry. The Malaysian government policies had been to facilitate the business environment for the palm oil industry to grow. The institutional policy networks link public institutions with palm oil firms and industry associations for exchanging information, expertise, trust and other political resources [31]. Many government ministries are involved in institutional policy networks within the palm oil industry [32]. Industry associations are involved in discussions, annual industry dialogues and sit on various governmental committees for inputs on policy-making. Common industry problems are regularly discussed. At theses dialogues, a united stance is arrived at to address these common industry problems.

Government-linked corporate networks are linkages among firms in which the government has significant direct ownerships. These government-owned firms are often provided with incentives to undertake projects or activities that can strengthen the palm oil industry through technology 
acquisition and infrastructure development. Moreover, government-linked palm oil firms own substantial acreage of plantation lands.

Government-owned companies, which are large palm oil firms, are instrumental in the generation and sharing of knowledge, with collaboration being an important $R \& D$ strategy.

An informant, who is an R\&D manager of a government-owned company, emphasized:

I strongly believe you cannot work in isolation. Gone are the days...collaboration is the right way. Number two...saving of resources. Internally we also like to work with others. For example, if we can get four people to work together, we spend less money to solve the problem. In fact next week, we have a seminar with company $\mathrm{X}$. When they have theirs, they invited us. Company $\mathrm{X}$ and us are close. Although we are competitors...but certain things we like to share.

Our research shows the long-term nature of research for a crop like oil palm requires palm oil firms to collaborate with other firms and governmental institutions to reduce costs and risks. As an example, the research to develop a new high-yielding oil palm can take over thirty years before a successful variety is commercialized for planting.

Thus, the nature of research involved in oil palm provides a strong motivation to collaborate, which leads to a permanent need of an institutional network. This is explained by an informant.

I think breeding has two elements. We can share the germplasms at the highest level...new material, which is a shared knowledge. As we go down, we become more secret. At the high level when the new material comes in why spend? It takes a lot of time. Why don't we share? Let us start with the basic information. We share with the original (information), after that we take it to our own programme...that becomes ours. I think collaboration is important for common knowledge. We do not mind like we do multi-locational breeding trials. This type of collaboration is of interest to the country. Why everybody spends the money on the same thing. We want to share knowledge, we don't spend unnecessarily.

The palm oil institutional network is supported by an informal personal network, which has been nurtured through a long history social interactions and personnel transfers between companies. Societies and communities form a strong informal network for knowledge sharing. An informant used the informal network extensively:

As a matter of fact, we have good working relationships with the MPOB, their senior staff...all of them are good friends. I am surrounded by good friends. What (info) MOPB cannot (provide), the
Incorporated Society of Planters (ISP) ${ }^{2}$ gives...I get to know the industry players through the ISP. When they have national seminars, more than 5,000 members will come. They also come for networking, meeting their friends. There is pride there!

The expert informational network (EIN) is a new type of network which is formally used by the Malaysian palm oil industry to search for new information and planning R\&D activities. The EIN is set-up by the government R\&D institute since its establishment thirty years ago, by appointing well-known experts to sit on a committee, named Programme Advisory Committee (PAC). This formal EIN allows the government R\&D institute to consider independent inputs for planning its $R \& D$ activities so as to balance the inputs of palm oil firms. As at April 2013, the PAC had sixty four members of experts from industry and academia.

The importance of the PAC is described by an informant, who is an R\&D manager:

The members of the PAC are very important. This is our number one technical structure. This is a unique structure. Many organizations are following our structure. Every division has the PAC. I find it very useful. We try all their visions. For me the industry is important...they are the ones who know the industry's needs. I think the network is extensive. Linking to the MPOB boost up their resumes...from there they get another reputation.

The role is further explained by an informant:

The PAC is important to the palm oil industry. One, those who are PAC members are the experts...the senior managers in their industries, not directly under the palm oil industry but various related fields like biology, technology in engineering and so on. The projects by these scientists in MPOB...it is good to have some kinds of approval from experts in the industry. At least some kinds of filtering to the demand of the industry!

The research shows the existence of close inter-organizational relationships among the palm oil firms, industry associations, $R \& D$ institutes, industry experts and academicians, and governmental units, which leads to the formation of a strong palm oil institutional network. The long history and economic importance of the palm oil industry to Malaysia encourages all the institutions to collaborate for the mutual benefit of the palm oil industry.

\section{Contribution to Theory}

The study contributes to the existing literature on inter-organizational relationships in the context of an

2 The ISP has been established in 1918. It is a society for plantation managers, and provides professional qualifications through a vigorous examination system, which is recognized by the plantation industry. 
innovation network in a developing country. The innovation network in the palm oil industry is based on close relationships between firms, industry collectives, governmental agencies and a government $\mathrm{R} \& \mathrm{D}$ institute for palm oil industry.

In this regard, the study adds to the understanding of an industry innovation system in a developing country by analyzing how firms and institutions direct their resources to search for information and allocate resources for research to solve industry problems. Central to this industry search efforts is an industry-funded $R \& D$ institute, which develops new knowledge for industry-wide adoptions. The relationships between the firms and institutions are characterized by on-going and regular interactions of firms and institutional actors at multiple levels. The outcome of these relationships is a continuous flow of new knowledge, which is translated into industry best-practices.

Another feature of the palm oil institutional network is the role played by an expert informational network for world-wide search of technological information and enhancing scientific credibility. The use of expert informational network for information search and for achieving scientific credibility in a developing country has not been well-researched.

The study also offers empirical support for the relational asset [6], which argues that the "network" is an important unit of analysis for explaining competitive advantage. The study demonstrates that a network can be more effective than a firm at the generation, transfer, and recombination of knowledge, especially in the context of a business environment in a developing country. It is shown that cooperation in the palm oil institutional network is due to the presence of trust among the individuals and organizations, as a result of repetitive interactions over decades. This study, thus, contributes to the literature on social capital in the context of an agro-industry in a developing country.

\section{Implications for Policy Makers and Managers}

The study shows that an innovation network, which involves inter-organizational relationships between collective actors, can make a difference to the technology trajectory of an industry. A main component of the innovation network is a government $\mathrm{R} \& \mathrm{D}$ institute for the palm oil industry, which acts as an orchestrator and catalyst to the innovation network. The government R\&D institute's expert informational network allows it to gain valuable legitimacy among the research and industry communities. The expert informational network is used to balance the short-term interest of the palm oil firms and the long-term need for exploratory research for the palm oil industry. The government $R \& D$ institute also is important in furthering the technological advancement of the palm oil industry due to its stable structure for accumulation of knowledge. The challenge of the government $\mathrm{R} \& \mathrm{D}$ institute is how to develop research programmes that can directly benefit the palm oil firms that contribute to its funding through cess collection.

The emphasis on the government R\&D institute to conduct research for the palm oil industry, however, may have an implication in that palm oil firms will have less motivation to develop their own research capabilities. In the long-run, these palm oil firms will not be able to develop their proprietary technologies for product differentiations. The study notes concerns that large palm oil firms are "under-investing" in R\&D activities because research activities are the responsibilities of the government R\&D institute.

Policy makers should analyze the effectiveness of the palm oil institutional network in developing new innovations as the structure of the palm oil industry changes over time. There is a recognition that the structure of the palm oil industry has changed, as Indonesia is now the leading producer of palm oil in the world. Malaysian policy makers will have to encourage palm oil firms to develop higher-valued proprietary products by expanding their search for innovations in networks, which are outside the existing palm oil institutional network. This could be achieved by developing new networks through their internationalization activities.

Managers should realize that firms are not atomistic units acting on their own in a faceless environment. They have to interact with other firms as well as non-firm institutions. Managers' actions can be described as a process of managing relationships in order to guarantee the control over resources, activities and even other actors so that the firm can achieve its objectives.

The study highlights the importance of a firm's ability to initiate, handle and use a portfolio of inter-organizational relationships. In order to achieve competitive advantages, firms need to build and increase their network competence through inter-organizational relationships, and they should identify their network relationships. In addition, firms should seek to develop and expand their external networks in order to meet the increased scope of their resource needs and resource challenges. Managers must accept that a firm's growth will be dependent on its networking activities, and they should consider entering networks whenever and in whatever way they can.

\section{Limitations of the Study}

The adoption of a research approach and the use of methods of collecting and analyzing data necessarily involve "trade-offs" [33]. The research outcomes generated demonstrate the value of qualitative approach used. Specifically, the findings show that the adoption of a qualitative approach and selection of the researcher as "instrument" for data collection and analysis enabled the researcher to get "close" to informants and developed with them trusting relationships. This has allowed the researcher 
to penetrate their realities and uncover issues relevance to understanding the research problem.

However, in common with any research project, the study was constrained by the method chosen. These constraints can be identified in two main areas. First, the grounded understanding of institutional networks requires that raw data were the experiences and perceptions of those involved in these networks. In collecting such data, it is possible, despite the sampling strategy and tactics employed, respondents were not always truthful. Second, the extent to which the findings to emerge from this research can be generalized to the wider populations of industry-based institutional networks is constrained. As the aim of this research was to generate substantive understanding rather than to test the validity and reliability of a hypothesis deduced from previous research, the findings that emerge from this study cannot be generalized to the wider population of the industrial sectors.

In addition, factors unique to the Malaysian palm oil industry may limit the applicability of the findings to other settings. The heavy resource dependence of the Malaysian palm oil firms on resources controlled by governmental agencies may, thereby, enhance the potential for relational effect. At the same time, the narrow focus that helps to control for industry and country-specific differences might have helped to mask significant effects.

The study involves a limited number of informants, who are senior managers of key institutions. The senior managers may have biased views on their inter-institutional relationships as they are the main actors. Due to time constraints and resources, the study was not able to include managers from smaller palm oil firms, representatives from less influential industry associations and junior executives of palm oil firms.

\section{Directions for Future Research}

It is noted that most of network-level studies were comparative in nature [34], although studies by some researchers restricted their analysis to only one network [35]. It is suggested that future research could compare the palm oil institutional network with the rubber institutional network. The rubber industry is not as large as the palm oil industry and has a government research institute. The palm oil institutional network could also be compared with the palm oil network in Indonesia, which is now the leading producer of palm oil. The Indonesian palm oil industry is relatively new as compared to the Malaysian palm oil industry.

The study captures the mechanisms for knowledge generation, sharing and adoption, which is facilitated by the palm oil institutional network. It did not analyze the effectiveness of knowledge sharing and knowledge transfers from the R\&D institute to the palm oil firms.

A distinctive feature of the palm oil institutional network is the use of the expert informational network. Future research could study the role of the expert informational network and its effectiveness in shaping the direction of the palm oil industry.

Finally, new research could examine whether external networks, such as the palm oil institutional network, which is to enhance industry-wide innovative capabilities, are conducive to the accumulation of internal capabilities of firms. In order to create value and competitiveness, firms should accumulate internal capabilities and develop external networks simultaneously.

\section{REFERENCES}

[1] UNCTAD. World investment report 2009: Transnational corporations, agricultural production and development, United Nation, New York, 2009.

[2] R. Rama (Ed.). Multinational agribusinesses, The Haworth Press, Inc., Binghamton, New York, 2005.

[3] A. MdNor. Internationalization of Malaysian palm oil multinationals, Journal of Palm Oil Economic Research, 2012, 12(1), 8-13.

[4] K. M. Eisenhardt. Building theory from case study research, The Academy of Management Review, 1989, 14(4), 532-550.

[5] H. Chen, T. J. Chen. Network linkages and location choice in foreign direct investment, Journal of International Business Studies, 1998, 29(3), 445-468.

[6] J. H. Dyer, H. Singh. The relational view: Cooperative strategy and sources of interorganizational competive advantage, Academy of Management Journal, 1998,23(4), 660-679.

[7] J. Nahapiet, S. Ghoshal. (1998). Social capital, intellectual capital, and the organizational advantage, Academy of Management Review, 1998, 21(2), 242-266.

[8] J. Jacobs. The death and life of great American cities, Peguin Books, London, 1995.

[9] F. Fukuyama. Social capital and the global economy, Foreign Affairs, 1995, 74(5), 89-103.

[10] D. Yiu, C. Lau, G. D. Brutun. International venturing by emerging economy firms: The effects of firm capabilities, home country networks, and corporate entrepreneurship, Journal of International Business Studies, 2007, 38, 519-540.

[11] D. Krackhardt. The strength of strong ties: The importance of philos in organizations. In N. Nohria \& R. G. Eccles (Eds.), Networks and organizations: Structure, form and action. Harvard University Press, Cambridge, 1992.

[12] B. Johannissson, M. Ramirez-Pasillas, G. Karlsson. The institutional embeddedness of local inter-firm networks: A leverage for business creation, Entrepreneurship \& Regional Development, 2002, 14, 297-315.

[13] J. Galaskiewicz. Has a network theory of organizational behaviour lived up to its promises?, Management and Organization Review,2007, 3, 1-18. 
[14] M. Storper. The resurgence of regional economies, ten years later: The region as a nexus of of untraded interdependence, European Urban and Regional Studies , 1995, 3, 191-221.

[15] M. Granovetter. Economic action and social structure: A theory of embeddedness, American Journal of Sociology, $1985,91,481-510$

[16] H. Hakansson, J. Johanson. Formal and informal cooperation strategies in international industrial networks. In F. Contractor \& P. Lorange (Eds.), Cooperative strategies in international business, Lexington Books, New York, 1988.

[17] J. H. Dyer, K. Nobeoka. Creating and managing a high-performance knowledge-sharing network: The Toyota case, Strategic Management Journal, 2000, 21, 345-367.

[18] S. Newell, J. Swan. Trust and inter-organizational networking, Human Relations, 2000, 53(10), 1287-1328.

[19] A. C. Inkpen, E. W. K. Tsang. Social capital, networks, and knowledge transfer, Academy of Management Review, 2005, 30(1), 146-165.

[20] B. Kogut. The network as knowledge: Generative rules and the emergence of structure, Strategic Management Journal, 2000, 21, 405-425.

[21] J. Pfeffer, G. R. Salancik. The external control of organizations: A resource dependence perspective, Harper and Row, New York, 1978.

[22] E. O. Laumann, J. Galaskiewicz, P. V. Marsden. Community structure as interorganizational linkages, Annual Review of Sociology, 1978, 4, 455-484.

[23] O. E. Williamson. Transaction cost economics: The governance of conractual relations, The Journal of Law and Economics, 1979, 22(2), 233-262.

[24] L. Tang. Interorganizational knowledge networks: The case of the biotechnology industry[PhD dissertation]. University of Southern California, 2007.

[25] W. W. Powell. Learning from collaboration, California Management Review, 1998, 40(3), 228-240.

[26] P. R. Monge, N. Contractor. Theories of communication networks, Oxford University Press, Oxford, 2003.

[27] G. Marwell, P. E. Oliver, R. Prahl. Social neworks and collective action: A theory of the critical mass. III, American Journal of Sociology, 1988, 94(3), 502-534.

[28] O. Shenkar, M. A. Von-Glinow. Paradoxes of organizational theory and research: Using the case of China to illustrate national contingency, Management Science, 1994, 40(1), 56-71.

[29] C. H. Cooley. Human nature and the social order, Schocken Books, New York, 1902.

[30] G. H. Mead. The philosophy of the act, University of Chicago Press, Chicago, 1938.

[31] P. Kenis, V. Schneider. Policy networks and policy analysis: Scrutinizing a new analytical toolbox. In B. Marin \& R. Mayntz (eds.), Policy Networks. Empirical Evidence and Theoretical Considerations. Frankfurt aM, Campus Verlag, 1991

[32] C. H. Teoh. The palm oil industry in Malaysia: From seed to frying pan, WWF Malaysia, Petaling Jaya, Selangor, 2002.

[33] M. Q. Patton. How to use qualitative methods in evaluation, Sage, London, 1987.

[34] K. G. Provan, A. Fish, J. Sydow. Interorganizational networks at the network level: A review of the empirical literature on whole networks, Journal of Management, 2007,33, 479-516.

[35] G. Soda, A. Usai, A. Zaheer. Network memory: The influence of past and current networks on performance, Academy of Management Journal, 47(6), 2004, 893-906. 